\title{
"It's the National Ethos, Stupid"! - Understanding the Political Psychology of the Israeli 2015 Elections Using Data from the National Resilience Survey
}

\author{
Eyal Lewin ${ }^{1}$ \\ ${ }^{1}$ Ariel University, Israel. \\ Correspondence: Eyal Lewin, Ariel University, Israel. \\ Received: May 9, 2016 \\ doi:10.11114/ijsss.v4i7.1651
}

\begin{abstract}
From a socio-political point of view, the results of the Israeli 2015 elections reflect an ongoing stagnation that is described in detail in this research. This stagnation is often explained by theories of social collective identities. However, none of the theories examines how group identities are created. Consequently, this study explains how different forms of national ethos shape political identities and interweave with them.

Relying on a wide set of data from the National Resilience Survey launched by the National Security Studies Center at Haifa University, this research examines the way Israeli political parties differ according to voters' attitudes on matters of national ethos. The findings show how opposing parties correspond with the two distinct forms of national ethos. However, the data also reveals that the ethos clash is not necessarily a dichotomy, but rather a continuum where various parties are located along a spectrum between the poles.
\end{abstract}

Keywords: group identity, national ethos, voter behavior, political stagnation, republicanism, liberalism.

\section{Introduction}

A friend of mine called me excitedly on the morning of March 17, 2015. "Would you believe it"? He could hardly conceal his agitation. "The Likud - they don't even have an ideological platform! I have been going through all the parties' websites to compare their ideas, and apparently the Likud did not even bother to publically declare any of their ideology"!

"If Likud did have a platform," I asked, "would you vote for them"?

"Of course not"! My friend exclaimed, "You know me - I have never considered Likud as an option"!

"In that case," I asked wryly, "why should Likud have an ideological platform"?

"You have a point there," my friend admitted.

"What's more," I concluded, "perhaps none of the parties really need a platform"!

As evening came that day, the tension in my political science class at the university was at its height, just like everywhere else in the country. Together with several of my students, who wanted to hear my analyses in real time, I was waiting for the television sample counts. When the time came and the counts were finally broadcast, I could repeat to my students exactly what I had been telling them for years now: there is nothing new. There is an ongoing minor electoral advantage for the right-wing parties, together with significantly better chances for them to form governmental coalitions. Borrowing from the words of Ecclesiastes, the thing that hath been is that which shall be; and that which is done is that which shall be done; and there is no new thing under the sun (Ecclesiastes 1:9, King James Bible).

From a socio-political point of view, the results of the 2015 elections reflect stagnation. It seems that the splits along social cleavages that shape Israeli society and divide it into its various groups have not changed for at least the last forty years. Although the left-right position allegedly embodies issue preferences mainly on the question of the occupied territories, the phenomenon of political stagnation is commonly explained by theories of political identity (Shaefer and Weimann, 2005).

There is considerable consensus that collective identities are central to politics. Much of the empirical foundation of this 
consensus derives from the correlations between social category membership and vote choice found in survey data (Dickson and Scheve, 2006). Group identity is considered a crucial factor in voter behavior because it involves a subjective sense of membership and tends to include self-concept and a perceived common fate. An individual is not merely aware of his membership in a certain group; social identity also involves the value and emotional significance that are attached to this membership (Tajfel, 1981). Hence understanding the psychology of group identity has long been perceived as an important key in gaining deep insights in the study of political behavior, and more specifically into voters' decisions. Social identities are often based on ethnicity, religion, gender, and other personal characteristics such as age and education; these are core factors that often generate political cohesion through shared concepts and by imposing conformity to certain norms of political activity (Huddy, 2001; 2003; Lewis-Beck et al., 2008; Miller et al., 1981; Simon and Klandermans, 2001).

Scholarly literature indicates that socio-demographic groups based on social class, age, gender, or marital status exhibit only very modest levels of political cohesion, whereas political identities prove much more effective. Partisanship and left-right ideology are collective identities that are considered to play a central role in shaping the dynamics of public opinion and electoral choice. Focusing on the American case, researchers have indicated how identifying with a particular party means not only holding a set of beliefs but also feeling a sense of psychological attachment to the political group. Thus, political identity entails abiding by norms concerning shared political beliefs and adopting the so-called correct group position on a political candidate, political party, policy issue, or a specific course of political action (Campbell. 1960).

The examples that researchers commonly use when analyzing political identities and their impact are not only Republican and Democrat in the U.S., Conservative and Labor in the U.K., Social Democrat and Christian Democrat in Germany, but also - Labor and Likud in Israel (Dalton, 2009; Lewis-Beck et al., 2008; Shamir and Arian, 1999).

However, most studies concentrate mainly on identity mobilization - that is, a given situation after an identity has already been acquired. The way group identities are created remains largely unexamined (Huddy, 2001). Partisan identity defines voter behavior, but does not necessarily indicate where it emerges from. Where, then, do identities in Israeli politics originate? Why do Israeli citizens choose to identify with a certain group, represented by a particular set of parties, and not to relate to another political environment? This study suggests that in Israeli politics the specific type of national ethos that people hold is the core factor that dictates, to a large extent, their political identity.

In order to comprehend the strange phenomenon of political stagnation in Israel, we shall first establish this situation based on election data since 1977. In an attempt to explain these unchanging outcomes, the theory of ethos clash in Israeli society will be introduced. Next, based on data stemming from a large national survey, our research will validate the assumption that fundamental concepts of one national ethos or another, which create group identity, form the core factor that eventually determines how people vote.

\section{The Israeli Case Study}

In order to understand the unchanging political setting, let us first present the protagonists of the Israeli political arena. Although names of parties change from time to time and parties tend to merge and to separate, to dissemble and to reassemble, the social groups remain the same. This principle is demonstrated in table 1: The Political Left-Right Stagnation, where the major actors of the Israeli political game are introduced. The reference in this paper is only to parties that succeeded in maintaining seats at Knesset.

Table 1. The Political Left-Right Stagnation

(Data taken from the Knesset official website: https://www.knesset.gov.il/history/eng/eng_hist_all.htm retrieved on October 1, 2015)

\begin{tabular}{|c|c|c|c|c|}
\hline \multirow[t]{2}{*}{ Year } & Left wing + Center + Arab parties & & Right wing + re & \\
\hline & Parties (seats) & $\begin{array}{c}\text { Total } \\
\text { number } \\
\text { of seats }\end{array}$ & Parties (seats) & $\begin{array}{c}\text { Total } \\
\text { number } \\
\text { of seats }\end{array}$ \\
\hline
\end{tabular}

1977 Labor (32); Ratz (1); Dash (15); Sheli (2); Lamed Ayin (1); Arab parties (6)

1981 Labor (47); Ratz (1); Shinuy (2); Telem (2); Arab parties (4)
$57 \quad$ Likud (43); Mafdal (12);

Shlomzion (2); Flatto Sharon (1);

Yahadut Hatora (5)

56

Likud (48); Mafdal (6);

Tehiya (3); Tami (3);

Yahadut Hatora (4) of seats

63 


\begin{tabular}{|c|c|c|c|c|}
\hline 1984 & $\begin{array}{l}\text { Labor (44); Ratz (3); Shinuy (3); } \\
\text { Yahad (3); Arab parties (6) }\end{array}$ & 59 & $\begin{array}{l}\text { Likud (41); Mafdal (4); } \\
\text { Tehiya (5); Tami (1); } \\
\text { Morasha (2); Kach (1); } \\
\text { Ometz (1); Shas (4); } \\
\text { Yahadut Hatora (2) }\end{array}$ & 61 \\
\hline 1988 & $\begin{array}{l}\text { Labor (39); Ratz (5); Shinuy (2); } \\
\text { Mapam (3); Arab parties (6) }\end{array}$ & 55 & $\begin{array}{l}\text { Likud (40); Mafdal (5); } \\
\text { Tehiya (3); Tzomet (2); } \\
\text { Moledet (2); Shas (6); } \\
\text { Yahadut Hatora (7) }\end{array}$ & 65 \\
\hline 1992 & $\begin{array}{l}\text { Labor (44); Meretz (12); } \\
\text { Arab parties (5) }\end{array}$ & 61 & $\begin{array}{l}\text { Likud (32); Mafdal (6); } \\
\text { Tzomet (8); Moledet (3); } \\
\text { Shas (6); Yahadut Hatora (4) }\end{array}$ & 59 \\
\hline 1996 & $\begin{array}{l}\text { Labor (34); Meretz (9); } \\
\text { Haderech Hashlishit (4); } \\
\text { Arab parties (9) }\end{array}$ & 56 & $\begin{array}{l}\text { Likud (32); Mafdal (9); } \\
\text { Israel Ba'aliya (7); Moledet (2); } \\
\text { Shas (10); Yahadut Hatora (4) }\end{array}$ & 64 \\
\hline 1999 & $\begin{array}{l}\text { Labor (26); Meretz (10); } \\
\text { Shinuy (6); Merkaz (6); } \\
\text { Am Echad (2); Arab parties (10) }\end{array}$ & 60 & $\begin{array}{l}\text { Likud (19); Mafdal (5); } \\
\text { Ichud Leumi (4); Israel Ba'aliya (6); } \\
\text { Israel Beytenu (4); Shas (17); } \\
\text { Yahadut Hatora (5) }\end{array}$ & 60 \\
\hline 2003 & $\begin{array}{l}\text { Labor (19); Meretz (6); } \\
\text { Shinuy (15); Am Echad (3); } \\
\text { Arab parties (8) }\end{array}$ & 51 & $\begin{array}{l}\text { Likud (38); Mafdal (6); } \\
\text { Ichud Leumi (7); } \\
\text { Israel Ba'aliya (2); } \\
\text { Shas (11); Yahadut Hatora (5) }\end{array}$ & 69 \\
\hline 2006 & $\begin{array}{l}\text { Kadima (29); Labor (19); } \\
\text { Meretz (5); Gimlaim (7); } \\
\text { Arab parties (10) }\end{array}$ & 70 & $\begin{array}{l}\text { Likud (12); Mafdal (9); } \\
\text { Israel Beytenu (11); Shas (12); } \\
\text { Yahadut Hatora (6) }\end{array}$ & 50 \\
\hline 2009 & $\begin{array}{l}\text { Kadima (28); Labor (13); } \\
\text { Meretz (3); Arab parties (11) }\end{array}$ & 55 & $\begin{array}{l}\text { Likud (27); Mafdal (3); } \\
\text { Ichud Leumi (4); } \\
\text { Israel Beytenu (15); } \\
\text { Shas (11); Yahadut Hatora (5) }\end{array}$ & 65 \\
\hline 2013 & $\begin{array}{l}\text { Labor (15); Meretz (5); } \\
\text { Yesh Atid (11); Hatnua (6); } \\
\text { Kadima (2); Arab parties (11) }\end{array}$ & 59 & $\begin{array}{l}\text { Likud + Israel Beytenu (31); } \\
\text { Mafdal (12); Shas (11); } \\
\text { Yahadut Hatora (7) }\end{array}$ & 61 \\
\hline 2015 & $\begin{array}{l}\text { Labor (24); Meretz (5); } \\
\text { Yesh Atid (11); Arab parties (13) }\end{array}$ & 53 & $\begin{array}{l}\text { Likud (30); Mafdal (8); } \\
\text { Israel Beytenu (6); Kulanu (10); Shas } \\
\text { (7); Yahadut Hatora (6) }\end{array}$ & 67 \\
\hline
\end{tabular}

\section{Legend}

Arab parties = several parties representing the Arab minority, counted here together

Am Echad $=$ a socialist faction of Labor

Dash $=$ a centralist party advocating democracy and change

Flatto Sharon $=$ a party led by Shmuel Flatto Sharon

Gimlaim = a party representing pensioners

Haderech Hashlishit = a party opposing withdrawal from the Golan Heights

Hatnua $=$ a liberal party

Ichud Leumi $=$ alliance of nationalist parties

Israel Ba'aliya $=$ a party that represented the interests of Russian Jewish immigrants

Israel Beytenu $=$ a securalist nationalist party

Kach $=$ a far-right nationalistic party

Kadima $=$ a centrist and liberal party advocating withdrawal from territories 
Kulanu $=$ a centrist party maintained mainly by former Likud activists

Labor $=$ social democratic former hegemonic party

Lamed Ayin $=$ a liberal party

Likud $=$ the major right-wing party

Mafdal $=$ the national religious party

Mapam $=$ a Marxist socialist workers' party

Meretz $=$ a secular social democratic party

Merkaz $=$ a center party

Moledet $=$ a party that advocated voluntary transfer of Arab population

Morasha $=$ a religious ultra-orthodox right-wing party

Ometz $=$ a right-wing party

Ratz $=$ a movement for civil rights and peace

Shas $=$ religious ultra-orthodox Sephardi party

Sheli $=$ a left-wing party advocating peace

Shinuy $=$ a secular anti-clerical free market liberal party

Shlomzion = a party led by Ariel Sharon

Tami $=$ a Jewish Sephardi ethnic party

Tehiya $=$ a right-wing party that supported Israeli sovereignty over the territories

Telem $=$ a party led by Moshe Dayan

Tzomet $=$ a secular right-wing party

Yachad $=$ a centrist party led by Ezer Weizman

Yahadut Hatora $=$ the representation of the religious ultra-orthodoxy

Yesh Atid = a secular middle class party

As seen in Table 1, there is an ongoing tide with one or two, sometimes even three or four, mandates moving from one political bloc to another. In 1992, a left wing government was formed for the first time, after five consecutive campaigns and 15 years of right-wing leadership. However, a close look into the way mandates were distributed reveals that Likud as the main right-wing party may have been defeated but the overall proportion between the two political blocs remained just the way it had been throughout the two decades that preceded the 1992 elections.

Another change allegedly took place between the 2003 and 2006 campaigns. In the course of three years, Likud dropped from 38 seats in the Knesset to 12 seats, the right wing lost 20 mandates and the left wing won them. This, again, was merely an illusion that corrected itself within the course of no more than another three years, in the 2009 campaign. The reason for the temporary change of the political map was the emergence of Kadima under the leadership of Ariel Sharon, former Likud leader. Since the roots of voter decision making are based on identities, Sharon could transfer thousands of settlers from their homes, and then transfer himself from the right wing to the left wing and still gain the support of the same electorate. With Sharon no longer around by 2009, the left wing shrank again into its natural less-than-sixty-seats situation and the system returned to its normal stagnation.

A simple arithmetical mean calculation summing all the left-wing mandates since 1977 (altogether 692) and dividing them by the number of Knesset election campaigns (12) leads to the conclusion that on average the left-wing maintains between 57 and 58 seats in the Knesset. Correspondingly, the right wing has on average a constant advantage of four to five mandates. The numbers, of course, do not necessarily reveal the ability or inability of each leading party, Likud on the right and Labor on the left, to establish a ruling coalition. Indeed, a national unity government was formed repeatedly throughout decades, institutionalizing the cooperation between parties of opposing political blocs.

\section{Theory}

Ethos is widely defined as the configuration of central societal beliefs that provide a particular orientation to a society. It combines dominant societal beliefs in a particular structure, and lends meaning to a specific group's societal life (Bar-Tal, 2000). The national ethos of a country is the array of particularistic-shared values and traditions from which a people's images of its future and its past are envisioned. The ethos integrates the community into a unit that believes in a 
common mutual destiny, and forms the foundation for its unique identity as a distinctive social group. The integrative ethos is also the moral source for the national community's informal social controls; it enforces commitments upon society and drives its members into a largely voluntary social order. Thus, the ethos of a nation holds in fact one of the most important keys to a people's ability to unite into a cohesive society (Etzioni, 2009).

The use of the expression in political science goes back to the German romanticism of the late $18^{\text {th }}$ century with philosopher Johann Gottfried Herder introducing the term Zeitgeist, which translates into "the spirit of the age." Inspired by philosopher Friedrich Hegel's concept of mind and moral fiber, Herder spoke of the cultural, ethical and political climate in which a nation evolves and crystallizes (Barnard, 2003). These ideas project a strong as sociation between the ethos of a nation and representations of the long history that the nation claims to have. The features of a community, some scholars claim, originated in the historical stages when the mental maps of the people, their prevailing culture, norms and ideas had first been cultivated (Rothstein, 2000).

In its national context, the idea of a collective memory resides deep in international studies theorist Benedict Anderson's comprehension of the nation as an imagined community. The national identity, according to Anderson, has a symbolic and constructed nature, and by utilizing the communications media it is capable of reaching dispersed populations (Anderson, 1983). The collective identity of a nation as a unique combination of a public that shares mutual values and beliefs that lie in its common narratives -- that is, its constructed collective memory -- and of the united role that its members believe fate has destined for them in this world. This is the national ethos, containing the foundation of the collective identity through both a sense of a certain duty that the nation is obligated to fulfill and a set of common goals that is intended for the people as a united entity to achieve (Lewin, 2012).

That being said, one should firmly bear in mind that the term "ethos," particularly national ethos, carries with it more than just accumulated and interpreted collective remembrances. It also encompasses the enduring shared beliefs that characterize a society. These beliefs are organized around leading themes, myths, values, ideologies, concerns, and the group's self-image; they form necessary conditions for the performance of social systems, functioning as lenses through which each member discerns the spirit of his social group (Bar-Tal, 2000; Giddens, 1984; Somers and Gibson, 1994).

Inquiring into the nature of different manifestations of national ethos reveals two distinct forms: a national republican ethos and a national liberal ethos. Whereas the former inspires fighting forces and struggling populations, the latter promotes deep beliefs in appeasement, reconciliation and pacification. The republican ethos can stimulate the mobilization of people into defending their country and serve as an inspiring instrument that will encourage them to bravely protect their national assets. A liberal ethos, on the other hand, can hardly tunnel collective energies into tasks where fierce fighting is needed (Lewin, 2014).

Within the Israeli society, an ongoing tussle plays out, where a national republican ethos and a national liberal ethos are constantly competing in an effort to shape the ideals of the nation, and consequently - to influence its future regarding some of the prominent issues that need collective decision making. At the beginning of the $21^{\text {st }}$ century, a clear competition can be delineated between two rival forms of Israeli national ethos: the republican ethos, deeply embedded in the traditional Zionist attitudes; and the liberal ethos, led primarily by believers in post-Zionist concepts.

The republican ethos was shaped and carved into the writings and opinions of various Zionist leaders throughout the $20^{\text {th }}$ century. Consolidated through decades of political and physical struggle, some of its values have eventually become the very principles of the State of Israel. Its core belief is the Zionist ideology and the particular doctrines that derive from it: the moral justification of a Jewish state in the Land of Israel, where all the Jews will gather and sustain their eternal historic continuity as a national community. Parallel doctrines consist of the denial of others' rights to settle the country, particularly the Palestinians, and of viewing their aspirations to do so as proof of vicious intentions to harass the Jewish people. Led by the republican ethos, Israeli culture and the Israeli education system established a national identity that was based on the concept that the State of Israel was under a constant and everlasting threat of extinction. In spite of the collective threat, according to the Israeli republican ethos, inherent Jewish strength enabled the nation to overcome its enemies by virtue of courage, diligence, ingenuity, and above all - moral superiority (Oren, 2009).

The liberal ethos has its roots in a post-Zionist attitude. During the 1980s a group of scholars known as the new historians cast doubt on the most basic Zionist ideology that provided the essential justification for Israel's very right to exist. Some of these scholars were more extreme than others, but altogether they drew a new historic picture, furnishing an alternative interpretation of the state's past, viewing the Zionist movement as a militant colonialist endeavor, based on the exploitation, subjugation and uprooting of the Arab population of the country. Sociologist Baruch Kimmerling was perhaps the first to point out how the Jewish state had been built on the ruins of an Arab society that supposedly existed on this territory for hundreds of years. The Jews, according to the new historic paradigm, took the 1948 war as an opportunity to inherit the country violently. The formation of Israeli society and the settlement of the land were based 
on incursion into a populated country and replacing its local indigenous inhabitants (Kimmerling, 1983; Pappe, 1992).

The rival forms of ethos totally contradict one another, they collide with each other, and they outline one of the deepest ideological cleavages that separates Israeli society - at times even tearing it up. No comprehension of the dynamics of Israeli politics can be fully achieved without a fundamental understanding of the clash between these different forms of ethos; no sociological analysis of Israeli society can be complete without an inquiry into these two contradictory doctrinal sets of values and beliefs that split the nation (Lewin, 2014).

This research examines, then, the way Israeli political parties differ according to voters' attitudes on matters of national ethos. I referred to four major issues of national ethos: (1) republican patriotism; (2) republican tendency to advocate siege mentality; (3) republican inclination towards trust in political leadership; (4) liberal support of the Supreme Court as the dominant social institute.

\subsection{Patriotism}

Patriotic loyalty is considered an unconditional love, a compulsive commitment to the object of admiration that eventually leads to what some scholars refer to as an obsessive dedication (Tamir, 1997). This point of view reveals a convention that when it comes to matters of war and peace, any personal logic should be rejected in the name of patriotism. In patriotic instances of sacrifice, people forfeit either years of their lives, their health, parts of their bodies, or their very existence for the sake of their country (Somerville, 1981).

Finding examples that fully envelop the attributes of patriotism is an easy task in the case of the Israeli republican ethos, because contemporary Israeli history is paved with events where people followed the patriotic pattern, forming - each in his own way - models for others to follow and imitate. Yet the ultimate exemplar, forming the archetype of a patriot within the Zionist legacy, is undoubtedly Joseph Trumpeldor. This Zionist leader was a Russian Jew who volunteered and excelled in the Russian army of the Russo-Japanese war. Later, he became a Zionist pioneer and was active in building Palestine and defending the Jewish settlements.

In 1920, when commanding a few untrained fighters and attacked by hundreds of Shiites, Trumpeldor was fatally shot. On his deathbed, he articulated the monumental statement that he had previously written in letters to his comrades, "never mind; it is good to die for our country." Trumpeldor's outstanding figure would from then on light the spirit of Jewish settlement and defense, his last words imprinted on the Zionist heritage, symbolizing the ultimate expression of Israeli love of country throughout ages to come (Segev, 1984).

The patriotic themes within the liberal ethos, on the other hand, are diminished by other current social trends. The globalization process, which immensely influences the liberal ethos, encourages individualism, which in turn jeopardizes the concept of supremacy of the national social group. Globalization, highly corresponding with modern capitalism, is considered to re-cast human behavior from that of a social animal into that of a homo economicus. Media, workplace and educational systems instill material self-interest as the leading social norm. Consequently, the more others are perceived as acting from self-interest, the more each citizen is encouraged to respond accordingly with a competitive attitude (Nikelly, 2000).

The primary assumption of the liberal ethos is that peace, rather than traditional national collective goals, is the sacred value for which mankind should strive. Moreover, the essence of the liberal ethos is the value of life. Land, history, and divine promises are no longer worth dying for when life is the alternative. In his March 13, 1995 speech for Trumpeldor's Memorial Day, Yitzhak Rabin rephrased the hero's last words, "it is good to die for our country"; claiming that death and bereavement are not destined by fate, he preached a reversal of Trumpeldor's heritage, coining a new conceptual sentence: "it is good to live for our country."

It seems, then, that the interpretation of patriotism through the lens of the liberal ethos leaves us with merely a shadow of patriotism. At the end of the day, whereas patriotism is in fact the backbone of the republican ethos, it is rather alien to the liberal ethos.

\subsection{Siege Mentality}

The republican ethos views Israel as still struggling, due to outbreaks of war from time to time, for its safety. Issues of national security are therefore naturally dominant, in line with the ways in which perceptions of citizenship and people's political standpoints are formed within this ethos. The more dangerous the situation is perceived to be, the more reality is viewed as a condition of siege, into which the whole country is put by its ruthless enemies (Arian, 1995; Horowitz, 1982).

The Holocaust, according to the republican ethos, was not the last historic experience of a nation that dwells alone. The chronicles of the Jewish-Arab conflict contributed to the development of a victimized self-perception and have been viewed as the direct continuation of the persecution of the Jewish people; accordingly, all of Israel's military activities 
have been perceived as acts of self-defense (Harkabi, 1977; Zafran, 2003).

Things look very different from the liberal ethos point of view; its basic claim is that its rival, the republican ethos, has built into the Israeli political culture a threat perception that leads extensively to militarism. Extreme emergencies, during which the very existence of a state is threatened from the outside, draw attention away from lesser domestic disputes and thus contribute to the consolidation of the political community (Evrigenis, 2008). Thus, a fairly cynical, though not necessarily unrealistic, viewpoint leads to the claim, on these grounds, that political leadership had better do its best to keep some of the threats active so that society continually demonstrates a rally-round-the-flag syndrome (Mueller, 1973).

The concept of a no-choice war, applied mainly to the 1948 war, has been replaced by the claim, held by liberal ethos proponents, that Israel has almost always chosen its wars. Even the defensive campaign of 1967, according to some liberal ethos believers, was not merely a reaction against aggressive Arab forces threatening to tear the small country apart, but rather a sequence of quarrelsome Israeli policies. According to a liberal historic perception, the Israeli nuclear breakthrough was the factor that persuaded Egyptian President Gamal Abdel Nasser to attack before the manufacture of an atomic bomb was completed (Aronson, 1992). Likewise, the frequent use of Israeli air power against the Syrians drove them to what eventually became a violent confrontation, not to mention the fact that capturing the Golan Heights was totally an Israeli initiative unnecessary for the termination of the 1967 war (Cohen, 1992).

\subsection{Political Trust}

Trust in political leadership is an important feature of republicanism. Beyond their commitment to republican norms of citizenship, people with the republican approach rely on one another to display their civil commitments. The republican citizens confidently put themselves in the hands of public officials - for example, politicians or bureaucrats - even when this trust is not supported by the existence of effective constraints on these officials. Republican citizens treat each other with the same social trust, and they are prepared to do so even when these fellow citizens are strangers. This willingness to accept an inevitable degree of trust in public authorities, relying almost blindly on their virtue, as well as the readiness to be vulnerable to other citizens, are essential conditions for a society to prosper, from the republican point of view. Political and social trust, according to republicanism, enable cooperation of associations and movements that eventually lead to social success (Pettit, 1999).

Republicans will be less skeptical of the possibility of state intervention, because they do not view state action, provided it is properly constrained, as an inherent affront to liberty. Hence, republican government may tend to be big in the range of responsibilities that it assumes, and often involves itself in five broad areas of policy making: external defense, internal protection, personal independence, economic prosperity, and public life (Ayres and Braithwaite, 1992; Pettit, 1999).

\subsection{Judiciary System}

Liberalism, in its essence, is focused on the individual. It stresses the human desire to live in a social and political environment where each person's inner complexity and creativity is acknowledged and respected. Liberalism's promise is to enable one to manifest different facets of his unique self and to enjoy a rich and varied inner life; it is the pursuit of personal happiness and the virtue of diversity and of individualism (Avnon and De-Shalit, 1999; Schwartzmantel, 1998).

Whereas republicanism advocates trust in the political system, liberalism seeks institutions that will eventually limit political leadership for the sake of maintaining individuals' rights. Montesquieu established the definitive language of liberalism by highlighting the ongoing tensions between power and liberty and by searching for regulating mechanisms that would ensure the superiority of civil rights (Manent, 1995).

The regulating social mechanism in Israeli society, according to the liberal approach, is the Supreme Court, as the final legal authority. The Supreme Court acts as a court of appeals from the rulings of the District Courts in criminal, civil, and administrative cases. It may issue orders for state authorities, local authorities, their officials and other bodies that fulfill public functions to perform various acts or to refrain from performing them. Particularly during recent decades, the Supreme Court has served as the leading institution in Israeli society for the promotion of human rights and liberal democratic values. Its rulings have shaped and buttressed protection of fundamental rights, even as the nation lacked a formal Constitution. In fact, there is wide consensus that the Supreme Court has formulated de-facto an unwritten bill of rights and court-protected fundamental rights, such as freedom of expression, using strict standards often borrowed from the American jurisprudence (Carmi, 2005).

\section{Method}

The data for this study stems from the National Resilience Survey launched annually since 2000 by the National Security Studies Center at Haifa University (Ben-Dor et al., 2014). This large poll encompasses a representative sample 
of the general Israeli adult population. At each point in time 2000 respondents are sampled, of which approximately 1600 are Jews. The data is gathered by means of identical large-scale telephone surveys. The questionnaires are also translated into Russian in order to ensure that the whole population is suitably covered, and consequently tested for validity and appropriateness in order to guarantee that they accurately reflect the Hebrew version. The survey questions are implemented by a Likert scale, where respondents are called to rate from 1 to 6 their acceptance of phrases that express the various factors that are inquired about.

The questions that were chosen for this study are those that enable us to focus on republican or liberal themes. Altogether, I have analyzed four themes represented by six sets of questions.

\subsection{Republican version of patriotism}

4.1.1. Questions regarding patriotism

I love Israel and I am proud of Israel.

When Israel is condemned abroad I feel irritated about it.

I am annoyed when the Israeli flag is being burnt.

A light threat on the security of the state is enough to justify a serious limit of democracy.

Israel is my home and I have no intention ever to leave it.

Every citizen ought to serve either in the military forces or in any other civil service.

4.1.2 Questions regarding collective self-justification

Israel has a just case in its disputes with other countries.

Every military Israeli action is a justified one.

\subsection{Republican tendency for siege mentality}

\subsubsection{Questions regarding fear of the enemy}

The threat posed by its enemies is very dangerous for Israel.

An enemy state might assault Israel.

4.2.2. Questions regarding militancy toward the enemy

It is important to implement military activity even if there are innocent casualties among the enemy's citizens.

Attacking Israel's enemies is essential in preventing future aggression of these enemies.

\subsection{Republican attitude towards trust in political leadership}

Rating trust in Knesset (1 to 6).

4.4. Liberal highlighting of the Supreme Court

Rating trust in the Supreme Court (1 to 6).

\section{Results}

The outcomes of the t-test that compares the means of the four different themes are presented here in table 2: The Left-Right Split Reflecting Ethos Clash in Israeli Society.

Table 2. The Left-Right Split Reflecting Ethos Clash in Israeli Society

\begin{tabular}{|c|c|c|c|c|c|c|c|c|c|c|}
\hline \multicolumn{2}{|c|}{ National ethos issues } & \multicolumn{3}{|c|}{ Left wing + center parties } & \multicolumn{6}{|c|}{ Right wing + religious parties } \\
\hline & & Meretz & Labor & $\begin{array}{l}\text { Yesh } \\
\text { Atid }\end{array}$ & Likud & Kulanu & $\begin{array}{c}\text { Israel } \\
\text { Beytenu }\end{array}$ & Mafdal & Shas & $\begin{array}{c}\text { Yahadut } \\
\text { Hatora }\end{array}$ \\
\hline \multirow[t]{3}{*}{ Patriotism } & Patriotism & 3.8056 & 4.6177 & 4.9964 & 5.2828 & 5.1379 & 5.3217 & 5.1883 & 4.5644 & 4.0312 \\
\hline & $\begin{array}{c}\text { Collective } \\
\text { self-Justification }\end{array}$ & & & & & & & & & \\
\hline & & 3.4032 & 4.3639 & 4.9632 & 5.3404 & 5.1765 & 5.1351 & 5.4667 & 5.3488 & 5.0290 \\
\hline $\begin{array}{c}\text { Siege } \\
\text { mentality }\end{array}$ & Fear of enemy & 3.0806 & 3.5121 & 3.6367 & 4.1401 & 3.8046 & 4.3275 & 3.5736 & 3.9778 & 3.4883 \\
\hline
\end{tabular}




\begin{tabular}{|c|c|c|c|c|c|c|c|c|c|c|}
\hline & Militancy & $2 / 3306$ & 3.4799 & 4.2212 & 4.9084 & 4.5584 & 4.8051 & 4.7861 & 4.9500 & 4.2419 \\
\hline \multirow[t]{3}{*}{ Trust } & $\begin{array}{c}\text { Political } \\
\text { trust }\end{array}$ & 2.8548 & 3.2064 & 3.0863 & 3.7096 & 3.0345 & 3.3158 & 3.8667 & 3.6000 & 2.4366 \\
\hline & $\begin{array}{c}\text { Trust in } \\
\text { Supreme court }\end{array}$ & & & & & & & & & \\
\hline & & 5.3548 & 5.1316 & 4.9638 & 3.9755 & 4.2209 & 3.8304 & 3.5210 & 2.8636 & 1.8592 \\
\hline
\end{tabular}

\section{Discussion}

An observation of the data makes clear that the distinct differences are those that occur between the two major rivals in the Israeli political arena, the Likud and Labor. On the republican themes, Likud means are significantly higher than those of Labor, with 5.2828 on patriotism as opposed to 4.6177 and even a larger gap of 5.3404 on collective self-justification as opposed to Labor's means of 4.3639. The means for fear of enemy assaults also reveal a significant gap between Likud, with 4.1401, and Labor, with 3.5121. Militancy means reveal even a sharper difference, with Likud's 4.9084 versus Labor's 3.4799. Accordingly, on the third theme of a republican scale, political trust, Likud voters have also higher means, 3.7096, in comparison with their Labor opponents whose means reach only 3.2064. When examining the liberal scale, where trust in the Supreme Court is measured, the scores are, consequently, switched, with Likud's means as low as 3.9755 and Labor's rising to 5.1316.

The differences between parties within each political camp also reflect closeness to the appropriate national ethos. Meretz is closer than Labor to the liberal ethos, in the sense that on each of the republican themes it scores lower means (particularly in patriotism, collective self-justification and militancy), and on the liberal scale referring to the Supreme Court it scores higher means of public trust. In the same sense one can observe how Yesh Atid, a center party that even participated in a right-wing government following the 2013 elections, is within the boundaries of the left wing, but scores means that resemble the results of voters from the right.

Inside the right-wing bloc, there is a difference between Likud and its religious partners, yet essentially one can observe how they are all much closer to the republican ethos than to the liberal one. Unsurprisingly, the liberal means of ultra-orthodox Shas and Yahadut Hatora voters are as small as 2.8636 (Shas) and 1.8592 (Yahadut Hatora), very significantly less than equivalent Likud means. On the republican scale, ultra-orthodox religious parties score less than Likud on the patriotic factor but score extensively higher on the scale of collective self-justification. There is a difference also between Shas, which is closer to the republican ethos, and Yahadut Hatora. Whereas Shas voters score high on themes of siege mentality, with 3.9778 for fear of enemy and 4.9500 for militancy, Yahadut Hatora's means are merely 3.4883 and 4.2419 respectively.

Mafdal's means are closer to the republican ethos on almost every theme than those of Likud, although the differences can be considered minor. Predictably, then, Mafdal voters' trust in the Supreme Court is lower than that of Likud voters.

Israel Beytenu also differs from Likud, and like Mafdal proves closer to the republican ethos. Although in themes of patriotism Avigdor Liberman's voters are slightly lower in means than their equivalent Likud supporters, on other themes they seem to be leading the republican story. The tendencies are a little mixed, but altogether both parties, Likud and Israel Beytenu, who have been in close partnership particularly during the previous campaign, indicate that they share a common republican national ethos.

An interesting case is that of Kulanu. This party allegedly used the ticket of a centrist party, just like Yesh Atid, focusing its propaganda on economic and cost-of-living issues. However, the party is led by Moshe Kahlon; Kahlon was elected to the Knesset during the 2000s after twice, consecutively, winning top places on Likud's list in the party's primaries (Haaretz, January 13, 2006). He was considered an outstanding minister in the Likud and Prime Minister Netanyahu even addressed his ministers in a government meeting on June 19, 2011, exclaiming "You should be Kahlon-ites"! (Haaretz, June 20, 2011). It is of no surprise, then, that Kulanu fixed its campaign on Likud voters using the slogan "A true Likudnik votes Kahlon." Consequently, the party's messages referred to Likud under Menachem Begin and called to continue the late leader's legacy (Haaretz, March 10, 2015). Indeed, in terms of national ethos Kulanu voters are in-between left and right, but somewhat closer in scores to Likud than to Yesh Atid.

\section{Conclusion}

On March 17, 2015, at exactly twenty-three minutes past noon, Prime Minister Binyamin Netanyahu posted a Facebook message, warning that the right-wing rule in Israel was in danger because the Arab voters were flocking in droves, as he put it, to the polling stations. Netanyahu indicated that Arab voters were bussed by left-wing NGOs and he urged his 
supporters to work harder and close the gap.

White House Spokesman Josh Earnest immediately called Netanyahu's appeal to his voters a cynical Election Day tactic, and noted that it was a transparent effort to marginalize Arab-Israeli citizens and their right to democratic participation. During the following weekend, President Barack Obama warned that Netanyahu's last-minute alarm call to his voters was endangering Israel's democratic foundations (The Times of Israel, March 25, 2015).

Likud's opponents at home proved cruder in their reactions. Yitzhak Herzog, the Labor Chairman who lost the election, slammed Prime Minister Binyamin Netanyahu in a series of meetings and TV interviews. According to Herzog, Netanyahu chose to humiliate 20 percent of Israeli citizens for the sake of his election campaign, and denied them the status that they deserve as citizens with equal rights. As stated by Herzog, in his harsh words against one-fifth of Israeli citizens, Netanyahu defied Jewish ethics and dismantled the human mosaic of Israeli society. When Herzog was asked, in an interview broadcast on the three national television channels 1,2 and 10, what he learned from the election results, his reply was: "There is a rightist public that is deeply connected to Likud that Netanyahu reached in the final days. He [Netanyahu] used the most fraudulent and racist utterances that exist. And it worked!" Herzog also commented that Netanyahu "more or less defined half the nation as traitors" (Lis, 2015).

Rabbah said: "A man is not held responsible for what he says when in distress" (Babylonian Talmud: Tractate Baba Bathra, Folio 16a. (1948). The Jews' College Translation. London, UK: Soncino Press). Yet Herzog's comments, as well as those made by the White House officials, indicate poor judgment - and above all, deep misunderstanding of Israeli politics. It was no coincidence that the joint Arab party running for the Knesset announced its major goal as preventing another right-wing government. The ambition of the Palestinian population - particularly the part of it that is considered moderate and refrains from violence - is to turn Israel from a Jewish state into a state that belongs equally to all its citizens. As Ayman Odeh, who heads the Arab party put it, when interviewed a few days before the elections: "I want two nations here by choice. I want two cultures here" (Schulman, 2015). In a passionate Martin-Luther-King-style speech in the Knesset, after the Arab party succeeded in gaining the unprecedented result of thirteen seats for Arab representatives, Odeh announced:

Recognition of national rights does not take anything away from the rest of the citizenry. [...] We will continue to demand to be recognized as a national group, which is entitled to full civil and national equality, and we will struggle for it (Green, 2015).

This study added to the common wisdom that identities are a key in voter behavior, the dimension of different forms of national ethos that shape identities and interweave with them. The research data demonstrates how left and right differ in their concepts on issues of national ethos, with right-wing voters tending to adopt republican attitudes of patriotism, siege mentality and trust in political leadership, whereas left-wing voters support a positive view of the Supreme Court. However, the data also reveals that the ethos clash should not necessarily be sketched as a dichotomy, but rather as a continuum where various parties are located on a spectrum between the two poles. When drawn rather as a scale, we can notice how republicanism and liberalism not only oppose each other but also intermingle. The centrist parties positioned at the left might show certain attributes of right-wing concepts in terms of trust in political leadership or high scores of patriotism; some religious parties situated at the right might prove low scores of patriotism resembling rather a liberal attitude.

Whether or not the solution to the tense relationship between Arabs and Jews within the mandatory borders of Israel (that is - without the Palestinians who live in the occupied territories) should be the abolition of the idea of Israel as a Jewish state is far beyond the scope of this paper. However, by joining the choir accusing Netanyahu - and therefore, his voters too - of racism, Herzog and other left-wing leaders have missed the point. On March 17, 2015, they lost the chance to be in power because at least for the last four decades, the identities that dictate the power structure of Israeli politics are shaped by the results of the ongoing struggle between the different forms of national ethos. The voters who took Netanyahu's warning seriously and headed to the polling stations did so because a liberal rival form of ethos was threatening their republican national ethos. If Likud voters drove in hordes to the polls, they did so because they feared those attempting to harm the idea of a Jewish state, whether they are anti-Zionist Arabs or Jews who adopted a liberal attitude.

Racism had nothing to do with the victory of the Likud. As always, it was all about identities, and most of all - the forms of national ethos that shape these identities. If ever asked for some good advice, I would enlighten Herzog and other left-wing leaders with the secret of the ongoing stagnation in Israeli politics by using a jokey variant of the snowclone imprinted by Bill Clinton's 1992 presidential campaign (Galoozis, 2012): it's the national ethos, stupid!

\section{Acknowledgements}

The data for this study was supplied by the National Security Studies Center at Haifa University, where the National 
Resilience Survey is annually launched since 2000.

\section{References}

Anderson, B. (1983). Imagined Communities. New York, NY: Verso.

Arian, A. (1995). Security Threatened: Surveying Israeli Opinion on Peace and War. Cambridge, UK: Cambridge University Press.

Aronson, S. (1992). The Politics and Strategy of Nuclear Weapons in the Middle East: Opacity, Theory, and Reality, 1960-1991: An Israeli Perspective. Albany, NY: State University of New York Press.

Avnon, D., \& De-Shalit, A. (1999). Introduction: Liberalism between Promise and Practice. In D. Avnon and A. De-Shalit (Eds.), Liberalism and Its Practice, London, UK: Routledge, 1-17.

Ayres, I., \& Braithwaite, J. (1992). Responsive Regulation: Transcending the Deregulation Debate. New York, NY: Oxford University Press, 1992.

Bar-Tal, D. (2000). Shared Beliefs in a Society: Social Psychological Analysis. Thousand Oaks, CA: Sage.

Barnard, F. M. (2003). Herder on nationality, humanity and history. Montreal, Canada: McGill-Queen's University Press.

Ben-Dor, G., Lewin, E., \& Canetti, D. (2014). The Social Ingredient of National Resilience: The Negotiation that Never Happened. Herzliya Conference IPS Policy Papers and Surveys. http://www.herzliyaconference.org/eng/?CategoryID=513\&ArticleID=2542

Campbell, A. P. E., Converse, W., Miller, E., \& Stokes, D. E. (1960). The American Voter. New York, NY: John Wiley \& Sons.

Carmi, G. E. (2005). A Constitutional Court on the Absence of a Formal Constitution? On the Ramifications of Appointing the Israeli Supreme Court as the Only Tribunal for Judicial Review. Connecticut Journal of International Law, 21(67), 67-90.

Cohen, A. (1992). Defending Water Resources: The Policy of Using Air Raids on the Israeli-Syrian Border. Tel Aviv, Israel: Ministry of Defense [Hebrew].

Dalton, R. J. (2009). The Good Citizen: How a Younger Generation Is Reshaping American Politics. Washington DC: CQ Press.

Dickson, E. S., \& Scheve, K. (2006). Social Identity, Political Speech and Electoral Competition. Journal of Theoretical Politics, 18(1), 5-39.

Etzioni, A. (2009). Minorities and the National Ethos. Politics, 29(2), 100-110.

Evrigenis, I. D. (2008). Fear of Enemies and Collective Action. New York, NY: Cambridge University Press.

Galoozis, C. (2012). It's the Economy, Stupid. Harvard Political Review. http://harvardpolitics.com/united-states/its-the-economy-stupid/

Giddens, A. (1984). The Constitution of Society. Cambridge, UK: Polity press.

Green, D. B. (2015). Jews and Arabs in Israel: Not Necessarily Enemies, says Israeli-Arab Leader. Haaretz.

Green, D. P., Palmquist, B., \& Schickler, E. (2002). Partisan Hearts and Minds: Political Parties and the Social Identities of Voters. New Haven: Yale University Press.

Harkabi, Y. (1977). Arab strategies and Israel's response. New York, NY: The Free Press.

Horowitz, D. (1982). The Israel Defense Forces: A Civilianized Military in a Partially Militarized Society. In R. Kolkowitz and A. Korbonski (Eds.), Soldiers, peasants and bureaucrats (pp. 117-134). London, UK: George Allen and Unwin.

Huddy, L. (2001). From Social to Political Identity: A Critical Examination of Social Identity Theory. Political Psychology, 22, 127-156.

Huddy, L. (2003). Group Identity and Political Cohesion. In D. Sears, L. Huddy and R. Jervis (Eds.), Oxford Handbook of Political Psychology, 511-558.

Kimmerling, B. (1983). Zionism and territory: The socio territorial dimension of Zionist politics. Berkeley, CA: University of California and Berkeley Institute of International Studies.

Lewin, E. (2012). National Resilience during War: Refining the Decision-Making Model. Lanham, MD: Lexington. 
Lewin, E. (2014). Ethos Clash in Israeli Society. Lanham, MD: Lexington.

Lewis-Beck, M. S., Jacoby, W., Norpoth, G. H., \& Weisberg, H. F. (2008). The American Voter Revisited. Ann Arbor, MI: University of Michigan Press.

Lis, J. (2015). Herzog: Netanyahu Humiliated Israeli Arabs to Garner Votes. Haaretz, March 21, 2015.

Manent, P. (1995). An Intellectual History of Liberalism. Princeton, NJ: Princeton University Press.

Miller, A. H., Gurin, P., Gurin, G., \& Malanchuk, O. (1981). Group Consciousness and Political Participation. American Journal of Political Science, 25, 494-511.

Mueller, J. E. (1973). War, Presidents and Public Opinion. New York, NY: John Wiley \& Sons.

Nikelly, A. G. (2000). Globalization and Community Feeling: Are They Compatible? The Journal of Individual Psychology, 56(4), 436-448.

Oren, N. (2009). The Israeli Ethos of Conflict, 1967-2006; Working Paper, 27. Arlington, VA: George Mason University - Institute for Conflict Analysis and Resolution.

Pappe, I. (1992). The making of the Arab-Israeli conflict, 1947-1951. London, UK: Tauris.

Pettit, P. (1999). Republicanism: A Theory of Freedom \& Government. Oxford, UK: Oxford University Press.

Roshwald, A. (2006). The Endurance of Nationalism: Ancient Roots and Modern Dilemmas. Cambridge, UK: Cambridge University Press.

Rothstein, B. (2000). Trust, Social Dilemmas and Collective Memories. Journal of Theoretical Politics, 12(4), 477-501.

Schulman, M. (2015). Israeli Election: What Do Israeli Arabs Want? Newsweek, March 6, 2015. http://www.newsweek.com/israeli-election-what-do-israeli-arabs-want-311979

Schwartzmantel, J. J. (1998). The Age of Ideology: Political Ideologies from the American Revolution to Postmodern Times. New York, NY: New York University Press.

Segev, T. (1984). 1949 - The First Israelis. Jerusalem, Israel: Domino Press, 1984.

Shamir, M., \& Arian, A. (1999). Collective identity and electoral competition in Israel. American Political Science Review, 93, 265-277.

Sheafer, T., \& Weimann, G. (2005). Agenda Building, Agenda Setting, Priming, Individual Voting Intentions, and the Aggregate Results: An Analysis of Four Israeli Elections, Journal of Communication, 55(2), 347-365.

Simon, B., \& Klandermans, B. (2001). Politicized Collective Identity: A Social Psychological Analysis. American Psychologist, 56, 319-331.

Somers, M. R., \& Gibson, G. D. (1994). Reclaiming the Epistemological "Other": Narrative and Social Construction of Identity. In C. Calhoun (Ed.), Social theory and politics of identity, 37-99.

Somerville, J. (1981). Patriotism and War. Ethics, 91(4), 568-578.

Tajfel, H. (1981). Human groups and social categories. Cambridge: Cambridge University Press.

Tamir, Y. (1997). Reflections on Patriotism. In D. Bar-Tal and E. Staub (Eds.), Patriotism in the lives of individuals and nations, 32-48. Chicago, IL: Nelson-Hall Publishers.

Zafran, A., \& Bar-Tal, D. (2003). Holocaust Memory and Its Implications for the Peace Process: The Influence of Fear and Self-image as a Victim on the Israeli Security Beliefs. In M. al-Haj and U. Ben-Eliezer (Eds.), In the Name of Security: the Sociology of Peace and War in Israel in Changing Times, 329-367. Haifa, Israel: Haifa University Press, 2003.

\section{(cc) $\mathrm{Br}$}

This work is licensed under a Creative Commons Attribution 3.0 License. 